\title{
A chorioidea vastagságának változása diabeteses betegekben
}

\author{
Horváth Hajnalka dr. ${ }^{* 1}$ - Ecsedy Mónika dr. ${ }^{* 1}$ - Kovács Illés dr. ${ }^{1}$ \\ Sándor Gábor László dr. ${ }^{1}$ - Mallár Klaudia dr. ${ }^{1}$ - Czakó Cecília dr. ${ }^{1}$ \\ Nagy Zoltán Zsolt dr. ${ }^{1}$. Somogyi Anikó dr. ${ }^{2}$
}

\author{
${ }^{1}$ Semmelweis Egyetem, Általános Orvostudományi Kar, Szemészeti Klinika, Budapest \\ ${ }^{2}$ Semmelweis Egyetem, Általános Orvostudományi Kar, Belgyógyászati és Hematológiai Klinika, Budapest
}

\begin{abstract}
Bevezetés: A swept source optikaikoherencia-tomográfia egy új, noninvazív eszköz, amely lehetővé teszi a retina mellett a chorioidea vizsgálatát, és segítséget nyújthat a diabeteses chorioidopathia patogenezisének megismerésében.

Célkitüzés: Diabeteses retinopathia különböző súlyosságú stádiumaiban a chorioideavastagság meghatározása, valamint a különböző terápiás lehetőségek és a jól ismert általános rizikófaktorok (a diabetes fennállási ideje, típusa, hemoglobin- $\mathrm{A}_{1 \mathrm{c}}$-szint, hypertonia) chorioideavastagsággal való korrelációjának meghatározása.

Módszer: Prospektív keresztmetszeti vizsgálat Swept Source DRI Triton optikaikoherencia-tomográfia segítségével. Macula- és chorioideavastagság-térképet készítettünk 60 diabeteses beteg 117 szeméről. Kontrollcsoportként 24 fó 45 szemét vizsgáltuk. A chorioideavastagság változásának a cukorbetegséggel, valamint a szisztémás rizikófaktorokkal való összefüggését elemeztük. A chorioideavastagság és a diabeteses retinopathia súlyossága (nincs, nonproliferatív/proliferatív stádium) közötti kapcsolatot, valamint a panretinalis lézerkezelés hatását is vizsgáltuk.

Eredmények: Cukorbetegekben szignifikánsan alacsonyabb chorioideavastagságot találtunk egészséges kontrollcsoporttal összehasonlítva $(\mathrm{p}<0,05)$. Az egész beteganyagot vizsgálva az életkor $(\mathrm{p}<0,001)$ és a hypertonia jelenléte $(\mathrm{p}<0,05)$ szignifikáns korrelációt mutatott a chorioidea elvékonyodásával. A cukorbetegség fennállási ideje és a chorioidea elvékonyodása között szignifikáns összefüggést mutattunk ki $(\mathrm{p}<0,05)$. A szisztémás rizikófaktorokat többváltozós modellben vizsgálva a betegség fennállási ideje a chorioideavastagság-csökkenés szignifikáns prediktora maradt $(\beta-0,18, \mathrm{p}=0,02)$. Szignifikánsan alacsonyabbnak találtuk a chorioideavastagságot a proliferatív retinopathiában szenvedő és a panretinalis lézerkezelésen átesett betegekben a nonproliferatív csoporttal összehasonlítva $(\mathrm{p}<0,05)$.

Következtetés: Vizsgálatunk igazolta, hogy a szisztémás rizikófaktorok (életkor, hypertonia, a diabetes fennállási ideje) mellett a diabetes jelenléte és a diabeteses retinopathia progressziója is hatással van a chorioidea elvékonyodására. A továbbiakban kimutattuk, hogy panretinalis lézerkezelés hatására a chorioideavastagság szignifikáns csökkenése figyelhető meg.
\end{abstract}

Orv Hetil. 2020; 161(35): 1475-1482.

Kulcsszavak: swept source optikaikoherencia-tomográfia, diabeteses retinopathia, chorioideavastagság

\section{Choroidal thickness changes in patients with diabetes}

Introduction: Swept-source optical coherence tomography is a useful non-invasive device that is used to understand better the role of choroid in the pathogenesis of diabetic retinopathy.

Aim: To measure choroidal thickness in diabetic eyes and to correlate it with established systemic risk factors, the severity and the therapy of diabetic retinopathy.

Method: Prospective cross-sectional study using swept-source optical coherence tomography has been performed. Choroidal and macular thickness maps of 117 eyes of 60 diabetic patients were compared to data from 45 eyes of 24 healthy controls. In all diabetic patients, the systemic risk factors (duration and type of diabetes, blood hemoglobin $A_{1 C}$ level, hypertension), the type (no, non-proliferative or proliferative) and the therapy of diabetic retinopathy were recorded, and their relation to choroidal thickness was evaluated using multiple regression models.

Results: A significantly thinner choroid was measured in diabetic patients compared to controls $(\mathrm{p}<0.05)$. Analysing the whole cohort, aging $(\mathrm{p}<0.001)$ and the presence of hypertension $(\mathrm{p}<0.05)$ showed significant correlation with choroidal thinning. In

${ }^{\star}$ Megosztott első szerzők. 
diabetic patients, the duration of diabetes significantly correlated with choroidal thinning $(\mathrm{p}<0.05)$. In multivariable analysis, the duration of diabetes remained a significant predictor of choroidal thickness $(\beta-0.18 ; p=0.02)$. A significantly thinner choroid was measured in patients with proliferative retinopathy and in patients after panretinal photocoagulation treatment compared to nonproliferative retinopathy $(\mathrm{p}<0.05)$.

Conclusion: Diabetes mellitus itself and diabetic retinopathy progression affects choroidal thickness significantly. Choroidal thickness is affected significantly by systemic risk factors (age, the presence of hypertension, disease duration). Choroidal thinning proved to be correlated with panretinal photocoagulation treatment of diabetic retinopathy.

Keywords: swept-source optical coherence tomography, diabetic retinopathy, choroidal thickness

Horváth H, Ecsedy M, Kovács I, Sándor GL, Mallár K, Czakó C, Nagy ZZs, Somogyi A. [Choroidal thickness changes in patients with diabetes]. Orv Hetil. 2020; 161(35): 1475-1482.

(Beérkezett: 2020. március 26.; elfogadva: 2020. május 5.)

\begin{abstract}
Rövidítések
ANOVA = (analysis of variance $)$ varianciaanalízis; $\mathrm{CV}=$ chorioideavastagság; $\mathrm{DM}=$ diabetes mellitus; $\mathrm{DMO}=$ diabeteses maculaoedema; DR = diabeteses retinopathia; EDI-OCT = enhanced depth imaging-OCT; ETDRS = Early Treatment Diabetic Retinopathy Study; ICGA = indocyanine green angiography; $\mathrm{HbA}_{1 \mathrm{c}}=$ hemoglobin- $\mathrm{A}_{1 \mathrm{c}} ; \mathrm{HT}=$ hypertonia; $\mathrm{OCT}=$ optical coherence tomography; NPDR = nonproliferatív (háttér-) retinopathia; $\mathrm{PDR}=$ proliferatív diabeteses retinopathia; $\mathrm{PRP}=$ panretinalis fotokoaguláció; $\mathrm{RPE}=$ retinal pigment epithelium; SD = spectral domain; SS = swept source; SS-OCT = Swept Source DRI Triton OCT; VEGF = vascular endothelial growth factor
\end{abstract}

A diabeteses retinopathia (DR) a megelőzhető vakság vezető okai közé tartozik a munkaképes felnőtt populációban világszerte, köztük hazánkban is [1]. A diabetes mellitus (DM) 15-20 éves fennállása után a 2-es típusú cukorbetegek 60\%-ában, míg az 1-es típusúak közel 100\%-ában kialakul a retinopathia [2].

Diabetesben a látáscsökkenés elsősorban a retina károsodásához köthető. A két legjelentősebb elváltozás, amely látásvesztéshez vezet, a proliferatív diabeteses retinopathia (PDR) és a diabeteses maculopathia [3]. A DM-ban kialakuló kisér-károsodás a capillariskeringés kiesésével ischaemiához vezet, valamint fokozza a vascularis endothelialis növekedési faktor (VEGF) termelődését, kóros érújdonképződést és fokozott érpermeabilitást okozva ezáltal [4]. A diabeteses maculopathia a DR bármelyik stádiumában kialakulhat. A világszerte mért vakság 4,8\%-áért felel, globális prevalenciája 7,8\% a diabeteses populációban $[3,5]$. Régóta ismert tény, hogy ez a két kórkép az anyagcsere-állapot és a magas vérnyomás szigorú kontrolljával megelőzhetővé válhat [3].

Az utóbbi években számos tanulmányban leírták a diabeteses chorioidea egyidejü elváltozásait is [6-8]. A chorioidea (érhártya) az uvea egy olyan magasan vaszkularizált és pigmentált része, mely a sclera lamina fusca rétege és a retinalis pigmentepithelium (RPE) között helyezkedik el, és elölről az ora serrata, hátulról a nervus opticus határolja. A chorioidea a külső retinarétegek (RPE, fotoreceptorok) vérellátásában fontos szerepet játszó szövet, az avascularis fovea önálló metabolikus forrása [9]. DM során számos patológiás változás jön létre a chorioideában: megnövekedett tortuositas (kanyargós erek), fokális vascularis dilatatiók, microaneurysmák és nem perfundált területek $[10,11]$. Hisztopatológiai és klinikai vizsgálatok eredményei igazolták, hogy számos chorioidealis keringési rendellenesség a DR patológiai változásai előtt megjelenhet, felvetve ezáltal a chorioidealis vasculopathia szerepét a DR patogenezisében $[11,12]$.

A chorioidea elhelyezkedéséből adódóan vizsgálata sokáig nehézségekbe ütközött. Mind ez idáig a chorioidea elemzéséhez indocianinzöld-angiográfia (ICGA), lézeres áramlásmérés (flowmetria) és ultrahang-technológia állt rendelkezésre, mely módszerek segítségével a chorioidealis erek és az áramlás rendellenességei vizsgálhatók, azonban egyik technika sem alkalmas pontos keresztmetszeti információ jellemzésére [9, 13]. A chorioidea háromdimenziós szerkezetének, rétegeinek elemzésére az optikaikoherencia-tomográfia (OCT) újgenerációs modelljei segítségével vált lehetőség [11]. A spectral domain (SD-) OCT háromdimenziós képeket készít a chorioideáról, a chorioidoscleralis határt 7496\%-os pontossággal képes ábrázolni. A SD-OCT új fejlesztése, a kiterjesztett mélységi képalkotás (enhanced depth imaging, EDI-OCT) szoftver kitüntetett pontokban készített manuális mérések felhasználásával képes a chorioidea morfológiájának és vascularisatiójának jellemzésére [14]. A legújabb, harmadik generációs OCTtechnológia, a swept source (SS-) OCT 1 mikron körüli hullámhosszal dolgozik, mely jobb penetrációs képességet jelent a SD-OCT-készülékek 800 nm körüli hullámhosszánál. A jobb áthatolóképességnek köszönhetően a vitreum, a chorioidea és a sclera egyidejúleg ábrázolható, elemezhető [15]. A SS-OCT további előnye az előző generációkhoz képest, hogy beépített szoftver segítségével végzi a chorioidea vizsgálatát, és háromdimenziós chorioideatérképek készítésére alkalmas, kikerülve ezáltal a manuális mérések okozta pontatlanságokat [16, 17]. 
Bár a diagnosztikus és terápiás lehetőségek egyre szélesebb spektruma van jelen a medicinában, DR esetében még nem érhető el a teljes gyógyulás. A szemészeti képalkotó vizsgálatok régóta meghatározó szerepet játszanak a DR szűrésében és követésében. A legújabb generációs noninvazív vizsgálómódszerek segítségével a patogenezis egyes olyan részletei is feltárulhatnak, melyek segítségével a látásromlást okozó szövődmények kialakulására fokozott rizikójú betegek hamarabb felismerhetővé/kezelhetővé válhatnak. A betegség patomechanizmusának pontosabb ismerete új támadáspontot nyújthat a gyógyszerek számára, esetleges végleges gyógyulást jelentve ezáltal.

Jelen tanulmányunk célja 1-es és 2-es típusú cukorbetegek chorioideavastagságának $(\mathrm{CV})$ vizsgálata a $\mathrm{DR}$ különböző súlyossági formáiban a legújabb generációs SS-OCT segítségével, valamint a különböző terápiás lehetőségek és a jól ismert általános rizikófaktorok (a DM fennállási ideje, típusa, hemoglobin- $\mathrm{A}_{1 \mathrm{c}}$-szint, hypertonia) [18] chorioideavastagsággal való korrelációjának meghatározása.

\section{Betegek és módszer}

A prospektív keresztmetszeti vizsgálatba (1-es és 2-es típusú) diabeteses betegeket, valamint kontroll-, nem diabeteses személyeket válogattunk be a Semmelweis Egyetem Szemészeti Klinikájának Retina Ambulanciáján 2017-ben vizsgált személyek közül. A tanulmány a Helsinki Deklaráció elveinek figyelembevételével, valamint az Intézményi Kutatásetikai Bizottság engedélyével zajlott. Tanulmányunkban összesen 60 diabeteses beteg 117 szemét (diabeteses csoport) és 24 kontroll egészséges személy 45 szemét (kontrollcsoport) elemeztük. A tanulmányból való kizárási kritériumként szerepelt a korábbi szemmütét (kivéve korábbi szürkehályog-mütét), egyéb szembetegségek, mint glaucoma, időskori maculadegeneratio, vitreomacularis betegségek, korábbi intravitrealis vagy subtenon gyógyszeres kezelés, klinikailag szignifikáns lencsehomályok jelenléte, valamint $\geq+3$ dioptria fénytörési hiba. A vizsgálatban rögzítettük a diabetes típusát, a glikált hemoglobin $\left(\mathrm{HbA}_{\mathrm{lc}}\right)$ értékét, a hypertonia (HT) jelenlétét, valamint a kórkép fennállási idejét. Az anamnézis felvételét követően valamennyi betegünk esetében automata refraktométerrel határoztuk meg a fénytörést, a látóélességet Kettesy-táblán vizsgáltuk, szemnyomást mértünk (Goldmann applanációs tonométerrel; Keeler Ltd., Windsor, Egyesült Királyság), a réslámpás vizsgálat után pupillatágításban a szemfeneket néztük át SuperField lencsével (Volk Optical Inc., Mentor, OH, USA). A diabeteses csoportban a DR diagnosztikáját és stádiumbeosztását az Early Treatment Diabetic Retinopathy Study irányelveinek megfelelően végezte két független, gyakorlott szemész szakorvos. A DR klinikai képe alapján diabeteses betegeinket három

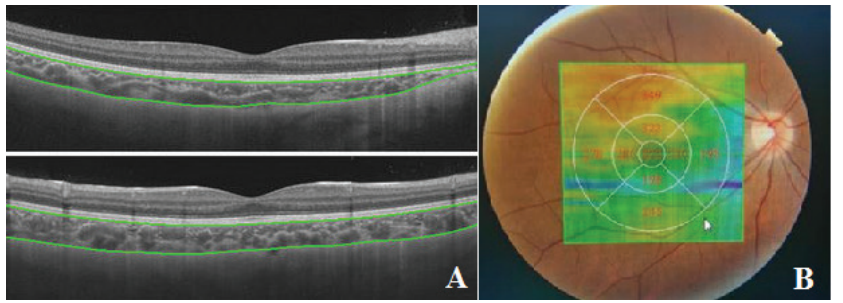

1. ábra

Egészséges beteg retina és chorioidea SS-OCT keresztmetszeti rétegfelvételi képe (a zöld vonalak a chorioidea határait jelzik) (A), valamint a színes szemfenéki felvételre illesztett chorioideavastagság-térkép az ETDRS (Early Treatment Diabetic Retinopathy Study) által ajánlott 9 macularis zóna feltüntetésével (B)

csoportra osztottuk - nincs DR, nonproliferatív (háttér-) retinopathia (NPDR) és proliferatív retinopathia (PDR) -, valamint rögzítettük a diabeteses maculaoedema (DMO) jelenlétét [19]. A maculaoedema diagnosztikus kritériumai az alábbiak voltak: kemény lipidexsudatumok lerakódása, microaneurysmák, valamint pontszerú bevérzések a fovea centrumától egy fovealis átmérőn belül a szemfenék biomikroszkópos vizsgálata során vagy a retina szerkezetének - SS-OCT-vizsgálattal igazolt megvastagodása $[19,20]$. PDR-t állapítottunk meg bármilyan retinalis neovascularisatio vagy üvegtesti bevérzés esetén [19]. Proliferatív retinopathiás betegeinket további két csoportra osztottuk - terápiában még nem részesült és a proliferáció miatt panretinalis fotokoagulációval (PRP) kezelt szemek - a PRP chorioideavastagságra gyakorolt hosszú távú hatásának vizsgálata céljából. Minden, a vizsgálatba bevont, terápiában részesült szem esetében a lézerkezelés minimum 3 hónappal megelőzte az OCT-vizsgálat idejét a fotokoagulációt közvetlenül kísérő - irodalmi adatokból ismert - átmeneti chorioideavastagodás miatt [21].

A chorioideavastagság mérését Swept Source DRI Triton OCT (Topcon Co., Tokió, Japán) segítségével végeztük el. Pupillatágítást (0,5\% tropikamid és $0,5 \%$ fenilefrin szemcsepp) követően a beépített 3D Macular Volumetric Raster Scan Protocol segítségével retina- és chorioideavastagság-térképet készítettünk a macularis $12 \times 9$ mm-es régióról (centrális fixáltatással). A chorioideavastagságot a retinalis pigmentepithelium hátsó pólusától a chorioidoscleralis junctio határvonaláig definiálják [22]. Vizsgálatunkban a beépített automata szoftver által kijelölt chorioideahatárvonal-illesztéseket minden esetben ellenőriztük, szükség esetén korrigáltuk. A CVértékeket az ETDRS által ajánlott 9 macularis zónában automata kalkulációval rögzítettük (centrális $1 \mathrm{~mm}$-es zóna - centrális subfovealis CV; valamint a 4-4 kvadránsra osztott 1-3 mm-es belső és 3-6 mm-es külső gyưrü) [19] (1. ábra). Teljes átlagos chorioideavastagságot a 9 macularis ETDRS-régió CV-értékének átlagolásával számoltunk. A CV ismert napszaki ingadozása miatt a mérések közel azonos időpontban, a kora délutáni órákban történtek [23]. 


\section{Statisztikai analizis}

A statisztikai teszteket SPSS programmal (SPSS 23.0, IBM, Armonk, NY, USA) végeztük. A csoportok közötti összehasonlításra ismétléses ANOVA-, majd Tukey post-hoc tesztet használtunk, miután az ismétléses teszt alkalmazásával lehetôvé válik, hogy figyelembe vegyük az egyazon személy két szemének adatai közötti korrelációt. A chorioideavastagságot és a DR stádiumát befolyásoló általános rizikófaktoroknak (életkor, a DM fennállási ideje, a DM típusa, $\mathrm{HbA}_{1 \mathrm{c}}$-szint, hypertonia) $[12,24$, 25] a chorioideavastagságra gyakorolt hatását egy- és többváltozós regressziós analízissel vizsgáltuk. A p-értéket statisztikailag szignifikánsnak tekintettük, amennyiben $\mathrm{p}<0,05$ volt.

\section{Eredmények}

Összesen 60 diabeteses beteg 117 szemét (diabeteses csoport) és 24 egészséges személy 45 szemét (kontrollcsoport) elemeztük. 42 férfi (31 diabeteses és 11 kontroll) és 42 nóbeteg (29 diabeteses és 13 kontroll) adatait vontuk be a vizsgálatba; diabeteses betegeink közül 24 (40\%) volt l-es típusú, míg 36 (60\%) 2-es típusú cukorbeteg. A teljes diabeteses beteganyag és a kontrollcso-

1. táblázat $\mid$ A vizsgált csoportok demográfiai és klinikai jellemzői

\begin{tabular}{|c|c|c|c|}
\hline & $\begin{array}{l}\text { Diabeteses csoport } \\
(\mathrm{n}=117) \\
\text { l-es típusú } \mathrm{DM} \\
(\mathrm{n}=47) \\
\text { 2-es típusú } \mathrm{DM} \\
(\mathrm{n}=70)\end{array}$ & $\begin{array}{l}\text { Kontroll- } \\
\text { csoport } \\
(n=45)\end{array}$ & p-érték \\
\hline $\begin{array}{l}\text { Nem, nő/férfi } \\
\text { 1-es típusú DM } \\
\text { 2-es típusú DM }\end{array}$ & $\begin{array}{l}58 / 59 \\
25 / 22 \\
33 / 37\end{array}$ & $24 / 21$ & $>0,05$ \\
\hline $\begin{array}{l}\text { Átlagéletkor, évek (SD) } \\
\text { 1-es típusú DM } \\
\text { 2-es típusú DM }\end{array}$ & $\begin{array}{l}59,26 \pm 13,86 \\
50,29 \pm 15,14 \\
65,29 \pm 8,86\end{array}$ & $59,8 \pm 16,78$ & $>0,05$ \\
\hline $\begin{array}{l}\text { A DM fennállási ideje, } \\
\text { évek (SD) } \\
\text { 1-es típusú DM } \\
\text { 2-es típusú DM }\end{array}$ & $\begin{array}{l}18,43 \pm 12,13 \\
23,45 \pm 9,98 \\
13,89 \pm 7,18\end{array}$ & & - \\
\hline $\begin{array}{l}H b A_{\mathrm{lc}} \%(\mathrm{SD}) \\
\text { 1-es típusú } \mathrm{DM} \\
\text { 2-es típusú } \mathrm{DM}\end{array}$ & $\begin{array}{l}7,64 \pm 1,11 \\
7,62 \pm 0,83 \\
7,65 \pm 1,27\end{array}$ & $5,42 \pm 0,37$ & $<0,0001$ \\
\hline $\begin{array}{l}\text { Hypertonia, igen/nem } \\
(\%) \\
\text { 1-es típusú DM } \\
\text { 2-es típusú DM }\end{array}$ & $\begin{array}{l}83 / 34(71) \\
23 / 24(48) \\
60 / 10(86)\end{array}$ & $18 / 27(40)$ & $<0,001$ \\
\hline $\begin{array}{l}\text { Legjobb korrigált látó- } \\
\text { élesség, decimális (SD) } \\
\text { 1-es típusú DM } \\
\text { 2-es típusú DM }\end{array}$ & $\begin{array}{l}0,61 \pm 0,37 \\
0,72 \pm 0,33 \\
0,54 \pm 0,38\end{array}$ & $0,78 \pm 0,32$ & $<0,01$ \\
\hline
\end{tabular}

Az adatokat átlag \pm szórás formában fejezzük ki.

$\mathrm{DM}=$ diabetes mellitus; $\mathrm{HbA}_{\mathrm{lc}}=$ hemoglobin- $\mathrm{A}_{\mathrm{lc}} ; \mathrm{SD}=$ standard deviáció port között nem volt statisztikailag szignifikáns különbség az életkor és a nem tekintetében $(\mathrm{p}>0,05,1$. táblázat). Az l-es típusú cukorbetegek átlagéletkora $(50,29 \pm 15,14$ év $)$ szignifikánsan alacsonyabb volt a 2 -es típusú diabetesesekkel $(65,29 \pm 8,86$ év, p>0,0001) és a kontrollcsoporttal $(59,26 \pm 13,86$ év, p $=0,002)$ összehasonlítva, míg a 2-es típusú cukorbetegek és a kontrollcsoport életkora között nem volt statisztikailag szignifikáns különbség ( $p>0,05)$. A hypertonia előfordulása szignifikánsan magasabb volt a diabeteses csoportban a kontrollcsoporttal összehasonlítva $(\mathrm{p}<0,05,1$. táblázat). A vizsgált csoportok fó demográfiai és klinikai jellemzőit az 1. táblázat tartalmazza összefoglalóan.

A 9 macularis ETDRS-régió chorioideavastagság-értékeiból számolt teljes átlagos CV és a centrális subfovealis régióban mért CV szignifikánsan alacsonyabb volt a teljes diabeteses beteganyagban a kontrollcsoporttal összehasonlítva (2. táblázat). l-es típusú cukorbetegek esetében a teljes átlagos és a centrális subfovealis régióban mért chorioideavastagság-értékek között sem igazolódott statisztikailag szignifikáns különbség a kontrollcsoporthoz viszonyítva (2. táblázat), ezzel szemben 2-es típusú DM-ban mind a teljes átlagos, mind a centrális subfovealis régióban szignifikánsan alacsonyabb CV-értékeket mértünk (2. táblázat). Az 1-es és 2-es típusú diabeteses betegek chorioideavastagság-értékeinek összehasonlítása során a centrális subfovealis régióban nem igazolódott különbség a két csoport között (266,62 \pm $84,86 \mu \mathrm{m}$ vs. $233,77 \pm 74,78 \mu \mathrm{m}, \mathrm{p}>0,05)$, míg a teljes átlagos CV szignifikánsan alacsonyabb volt a 2-es típusú DM-ban szenvedő betegek esetében $(250,31 \pm 83,99$ $\mu \mathrm{m}$ vs. $215,85 \pm 69,49 \mu \mathrm{m}, \mathrm{p}<0,003)$.

A korábban említetteknek megfelelően diabeteses betegeinket a DR klinikai képe alapján három csoportra

2. táblázat A diabeteses betegek és a kontrollcsoport chorioideavastagságértékei

\begin{tabular}{lllll}
\hline & $\begin{array}{l}\text { Centrális } \\
\text { subfovealis CV, } \\
\mu \mathrm{m}(\mathrm{SD})\end{array}$ & p-érték & $\begin{array}{l}\text { Teljes átlagos } \\
\mathrm{CV}, \mu \mathrm{m}(\mathrm{SD})\end{array}$ & p-érték \\
\hline $\begin{array}{l}\text { Kontroll- } \\
\text { csoport } \\
(\mathrm{n}=45)\end{array}$ & $279,89 \pm 80,95$ & - & $263,23 \pm 72,96$ & - \\
\hline $\begin{array}{l}\text { Diabeteses } \\
\text { csoport } \\
(\mathrm{n}=117)\end{array}$ & $246,97 \pm 80,27$ & $<0,01$ & $229,69 \pm 77,18$ & $<0,004$ \\
\hline $\begin{array}{l}\text { l-es típusú } \\
\text { DM } \\
(\mathrm{n}=47)\end{array}$ & $266,62 \pm 84,86$ & $>0,05$ & $250,31 \pm 83,99$ & $>0,05$ \\
\hline $\begin{array}{l}2 \text {-es típusú } \\
\text { DM } \\
(\mathrm{n}=70)\end{array}$ & $233,77 \pm 74,78$ & $<0,007$ & $215,85 \pm 69,49$ & $<0,003$ \\
\hline
\end{tabular}

Az adatokat átlag \pm szórás formában fejezzük ki.

A p-értékek a kontrollcsoporthoz viszonyított szignifikanciaszinteket jelölik.

$\mathrm{CV}=$ chorioideavastagság $; \mathrm{DM}=$ diabetes mellitus; $\mathrm{SD}=$ standard de viáció 


\begin{tabular}{llllll}
\hline & & Centrális subfovealis $\mathrm{CV}, \mu \mathrm{m}(\mathrm{SD})$ & p-érték & Teljes átlagos CV, $\mu \mathrm{m}(\mathrm{SD})$ & p-érték \\
\hline \multirow{2}{*}{ Diabeteses maculaoedema } & $\mathrm{Nem}(\mathrm{n}=57)$ & $260,15 \pm 92,38$ & - & $243,3 \pm 19,57$ & - \\
\cline { 2 - 6 } & $\operatorname{Igen}(\mathrm{n}=60)$ & $240,37 \pm 73,23$ & $>0,05$ & $222,48 \pm 20,35$ & $>0,05$ \\
\hline \multirow{2}{*}{ Proliferatív retinopathia } & $\operatorname{Nem}(\mathrm{n}=80)$ & $264,54 \pm 60,54$ & - & $249,39 \pm 23,32$ & - \\
\cline { 2 - 7 } & $\operatorname{Igen}(\mathrm{n}=37)$ & $229,94 \pm 81,02$ & 0,01 & $213,15 \pm 20,18$ & $<0,001$ \\
\cline { 2 - 7 } & $\operatorname{PRP}-k e z e l t(\mathrm{n}=21)$ & $221,13 \pm 68$ & 0,007 & $208,18 \pm 21,12$ & $<0,001$ \\
\hline
\end{tabular}

Az adatokat átlag \pm szórás formában fejezzük ki.

$\mathrm{CV}=$ chorioideavastagság; $\mathrm{PRP}=$ panretinalis fotokoaguláció; $\mathrm{SD}$ = standard deviáció

osztottuk: nincs DR $(\mathrm{n}=18)$, nonproliferatív retinopathia $(\mathrm{n}=62)$ és proliferatív retinopathia $(\mathrm{n}=37)$. A vizsgálatba bevont 37 , proliferatív retinopathiás szem közül 16 szem esetében még nem történt panretinalis fotokoaguláció, míg 21 szem - a vizsgálatot legalább 3 hónappal megelőzően - lézerkezelésen már átesett. A centrális subfovealis és a teljes átlagos chorioideavastagságot szignifikánsan alacsonyabbnak találtuk a proliferatív retinopathiában szenvedő és a panretinalis lézerkezelésen átesett betegekben a nonproliferatív csoporttal összehasonlítva (3. táblázat). Diabeteses maculaoedemát 60 szem esetében detektáltunk (51\%). Nem igazolódott szignifikáns különbség a DMO nélküli és a maculopathiában szenvedő betegek chorioideavastagság-értékei között (3. táblázat).

A szisztémás rizikófaktorok és a chorioideavastagság kapcsolatának vizsgálata során - az egész beteganyagot vizsgálva - szignifikánsan vékonyabb chorioideavastagság-értékeket mértünk a hypertoniásokban a nem hypertoniásokkal összehasonlítva $(234 \pm 81 \mu \mathrm{m}$ vs. $270 \pm 90$ $\mu \mathrm{m}$ teljes átlagos $\mathrm{CV} ; \mathrm{p}<0,05)$. Az életkor szignifikáns korrelációt mutatott a chorioidea elvékonyodásával a teljes macularis régióban $(30 \mu \mathrm{m} / 10$ év; $\mathrm{p}<0,001)$

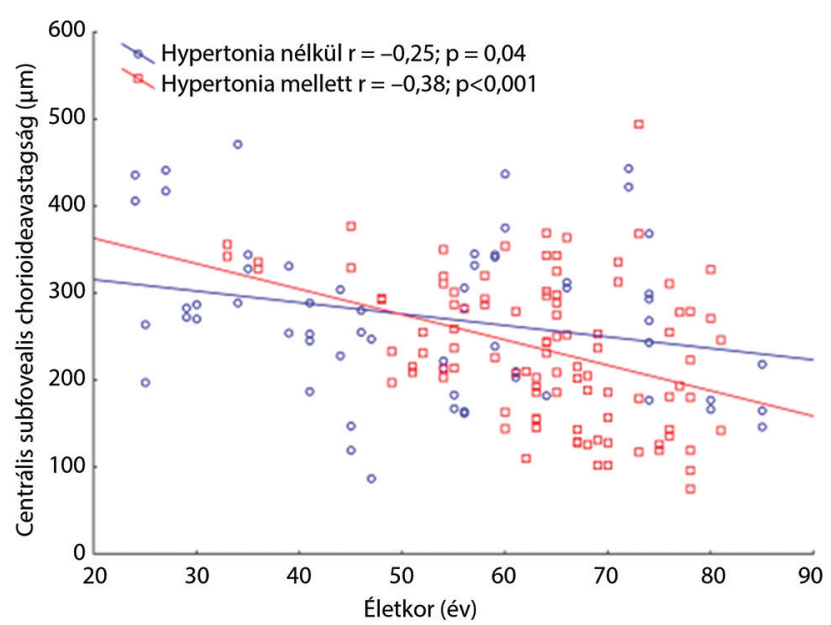

2. ábra

Centrális subfovealis chorioideavastagság $(\mu \mathrm{m})$ összehasonlítása az életkor függvényében hypertoniás és nem hypertoniás betegekben
(2. ábra). A diabeteses csoportot vizsgálva nem igazolódott szignifikáns összefüggés a betegség típusa, a $\mathrm{HgA}_{1 c^{-}}$ szint és a CV-értékek között $(p>0,05)$. Ezzel szemben a cukorbetegség fennállási ideje és a chorioidea elvékonyodása között szignifikáns összefüggést mutattunk ki (15 $\mu \mathrm{m} / 10$ év a teljes macularis régióban; $\mathrm{p}<0,05$ ). A szisztémás rizikófaktorokat többváltozós modellben vizsgálva a betegség fennállási ideje a CV-csökkenés szignifikáns prediktora maradt a teljes macularis régióban $(\beta-0,18, p=0,02)$, az egyéb szisztémás rizikófaktorok (életkor, hypertonia, $\mathrm{HgA}_{\mathrm{lc}}$-szint, a diabetes típusa) hatását figyelembe véve.

\section{Megbeszélés}

Diabetes mellitusban a látáscsökkenés elsősorban a retina károsodása következtében kialakuló diabeteses retinopathiához és diabeteses maculopathiához köthető, számos tanulmányban leírták azonban a chorioidea egyidejű elváltozását, a diabeteses chorioidopathiát. Ezen tanulmányokban szövettani vizsgálatok, indocianinzöldangiográfia, lézerflowmetria és OCT-vizsgálatok segítségével kimutatták, hogy számos chorioidealis keringési rendellenesség a DR patológiai változásai előtt megjelenhet $[6,7,10,11,26]$. Szövettani vizsgálatok során kimutattak chorioidealis elváltozásokat cukorbetegekben a diabeteses retinopathia klinikai tünetei nélkül (elzáródások a choriocapillarisokban, a chorioidealis erek bazálmembránjának megvastagodásai, megnövekedett tortuositas, fokális vascularis dilatatiók, microaneurysmák), felvetve ezáltal a chorioidea szerepét a diabeteses retinopathia későbbi patogenezisében $[10,11]$. Lézerflowmetriás vizsgálatok a chorioidealis vérkeringés progreszszív csökkenését írták le olyan betegeknél, akiknél a DR szemfenéki jelei még nem voltak detektálhatók $[6,7]$. Ezen eredmények alapján egyes szerzők felvetették a chorioidealis hypoperfusio lehetőségét a DR kialakulásában kulcsszerepet játszó retinális szöveti hypoxia és a következményes VEGF-felszabadulás hátterében l-es és 2 -es típusú cukorbetegekben is $[6,7]$.

Jelen tanulmányunkban - korábbi vizsgálatok eredményeit megerôsítve - az általunk vizsgált teljes diabeteses beteganyag, valamint a 2 -es típusú cukorbetegek chorio- 
ideavastagságát szignifikánsan alacsonyabbnak találtuk a 9 macularis ETDRS-régióban egészséges kontrollcsoporttal összehasonlítva $[8,26,27]$. Querques és mtsai a CV szignifikáns csökkenését mutatták ki 2-es típusú diabeteses betegekben a DR szemfenéki tünetei nélkül, megerősítve ezáltal azon hipotézis lehetőségét, miszerint a csökkent chorioidealis keringés a DR kialakulásának egyik primer eseménye lehet [28]. Az 1-es és 2-es típusú cukorbetegek chorioideavastagságának összehasonlítása során a 2-es típusú diabetes mellitusban szenvedő betegek teljes átlagos chorioideavastagsága szignifikánsan alacsonyabb volt az 1-es típusúakkal összehasonlítva, ezen eredményünket azonban a 2-es típusú cukorbetegek szignifikánsan magasabb életkora is befolyásolhatja (irodalmi adatokból ismert egészséges populációban a CV életkorral összefüggő csökkenése) [24].

Tekintettel arra, hogy a cukorbetegség szemészeti szövődményei 1 -es és 2 -es típusú diabetes mellitusban megegyeznek [5], a diabeteses retinopathia stádiuma és a chorioideavastagság kapcsolatának vizsgálata során a teljes diabeteses beteganyag adatait együttesen elemeztük. Eredményünk, miszerint a betegség progressziójával a chorioideavastagság csökkenését mutattuk ki, megegyezik több, korábbi tanulmány eredményével $[8,11,27$, 29]. Vizsgálataink során a proliferatív retinopathiában szenvedő betegek CV-át szignifikánsan alacsonyabbnak találtuk a nonproliferatív csoporttal összehasonlítva (eredményünket azonban befolyásolhatja, hogy ezen csoportban a betegek egy része panretinalis lézerkezelésben részesült). Néhány, spectral domain OCT-vel végzett tanulmányban ezzel szemben a chorioideavastagság fokozódását találták a retinopathia progrediálása során [30]. A CV és a diabeteses maculopathia kapcsolatát vizsgáló tanulmányok eredményei is ellentmondásosak. Számos, spectral domain és swept source OCT-vel végzett tanulmányban a chorioideavastagság szignifikáns csökkenését írták le DMO mellett [26, 28, 31], míg egyes közleményekben nem találtak összefüggést a CV és a maculopathia jelenléte között [29, 32]. Vizsgálataink során nem igazolódott szignifikáns különbség a DMO nélküli és a maculopathiában szenvedő betegek chorioideavastagság-értékei között.

Ezen ellentmondásos eredmények hátterében a chorioideának az elhelyezkedéséből adódó nehezebb vizsgálhatósága és ebből fakadóan a különböző tanulmányok során alkalmazott, nem egységes vizsgálómódszerek állhatnak $[6,7]$. Az OCT-technológia a szemfenéki diagnosztika új mérföldkövét jelentette, az in vivo, noninvazív módon készített fénymikroszkópos feloldóképességú keresztmetszeti képek segítségével az eltérő optikai denzitású területek elkülöníthetővé váltak [33]. A SD-OCT új fejlesztése, az EDI-OCT szoftver lehetővé tette a chorioidea részletes elemzését. A szoftver kitüntetett pontokban készített manuális mérések felhasználásával képes a chorioidea szerkezetéról, vastagságáról és a chorioidoscleralis határról információt szolgáltatni, a különböző pontokban történő mérések azonban nem reprezen- tálják pontosan a teljes macula chorioidealis vastagságát [14]. A legújabb generációs swept source OCT technológia ezzel szemben beépített szoftver segítségével végzi a chorioidea vizsgálatát, és háromdimenziós chorioideatérképek készítésére is alkalmas, így pontosabb és reprodukálhatóbb eredményekkel szolgálhat a chorioideavastagságról az EDI-OCT-vel összehasonlítva [15-17]. Ezenfelül a SS-OCT 1 mikron körüli hullámhosszal dolgozik, ami jobb penetrációs képességet jelent a SD-OCT készülékek 800 nm körüli hullámhosszánál [17]. A SSOCT gyorsabb felvételkészítést is lehetővé tesz, 100000 $\mathrm{Hz}$ (A-scan/s - amplitude scan/s) sebességgel dolgozik, a második generációs SD-OCT-technológia $40000 \mathrm{~Hz}$ (A-scan/s) sebességével összehasonlítva [16]. Tanulmányunkban ezen előnyök miatt döntöttünk a SS-OCT használata mellett. Legjobb tudomásunk szerint munkacsoportunk elsőként vizsgálta a diabeteses retinopathia és a chorioideavastagság kapcsolatát a hazai irodalomban [27].

Tanulmányunkban a diabeteses retinopathia terápiás lehetőségei közül a panretinalis lézerkezelés chorioideavastagságra gyakorolt hatását is vizsgáltuk. Lézer-fotokoguláció során a fény energiájának segítségével a retinalis érújdonképződés megakadályozható, és így a látásélesség megóvható [34]. Több korábbi, Doppler-flowmetria és OCT segítségével végzett tanulmányban, röviddel a lézerkezelés után ( 1 hét-1 hónap), a macularis CV szignifikáns növekedéséről számoltak be [21, 35]. A szerzők feltételezése szerint ennek hátterében a lézerkezelés által indukált lokális chorioidealis gyulladásos reakció/obstrukció állhat, melynek következtében vasodilatatiót és következményes fokozott chorioidealis vérkeringést detektáltak a nem kezelt macularis területeken, röviddel a terápia után $[6,7]$. Ezen eredmények ismeretében tanulmányunkban a lézerkezelés minden, a vizsgálatba bevont, terápiában részesült szem esetében minimum 3 hónappal megelőzte az OCT-vizsgálat idejét. Eredményünk, miszerint a panretinalis lézerkezelésen átesett betegek chorioideavastagságát szignifikánsan alacsonyabbnak találtuk a nonproliferatív csoporttal összehasonlítva, egyezik több korábbi tanulmány eredményével [36, 37]. Zhang a panretinalis lézerkezelés utáni, hosszú távú chorioideavastagság-csökkentés hátterében három lehetséges patomechanizmust is feltételez: (1) a fotokoaguláció által kiváltott termális hókárosodás meggátolja a chorioideareperfúziót, CV-csökkenést eredményezve ezáltal; (2) a PRP a RPE-ra gyakorolt károsító hatás mellett csökkenti a VEGF-felszabadulást, mely folyamatok következtében csökken a chorioidealis erek dilatatiója és permeabilitása; (3) a külső retina lézerkezelés okozta károsodása következtében a hypoxiás belső retina közelebb kerül a magasan vaszkularizált choriocapillaris réteghez, autoregulációt és következményes csökkent chorioideakeringést indukálva ezáltal [21]. Vizsgálati eredményünk, miszerint minimum 3 hónappal a lézerkezelés után a CV szignifikáns csökkenését tapasztaltuk, ezen hipotézisekkel korrelál. A továbbiakban a patomechaniz- 
mus pontosabb feltárása érdekében a mikrocirkuláció kvalitatív és kvantitatív vizsgálatára alkalmas OCT-angiográfia nyújthat majd segítséget.

Számos korábbi tanulmányban leírásra került, hogy a CV jelentős különbségekkel jár az életkor, a refrakció és a napszak vonatkozásában $[24,38]$. Tekintettel a chorioideavastagság ismert diurnalis változására (a késő délutáni órák során a legvékonyabb és a hajnali órákban a legvastagabb), vizsgálatainkat azonos időpontban (kora délutáni órák) végeztük [23]. Figyelembe véve az elmúlt évek során több tanulmány által igazolt összefüggést a szem tengelyhossza és a CV között, vizsgálatunkból kizártunk minden olyan beteget, akinél $\geq+3$ dioptria fénytörési hibát találtunk automata refraktometriás vizsgálat során [24, 38]. Számos korábbi tanulmányban leírták a chorioideavastagság és a diabeteses retinopathia patogenezisében is szerepet játszó szisztémás faktorok - életkor, hypertonia, a diabetes fennállási ideje, típusa, $\mathrm{HbA}_{1 \mathrm{c}}$-szint - kapcsolatát $[18,22,24]$. Egészséges populációban a chorioideavastagság életkorral összefüggő csökkenését igazolták [24, 38]. A vizsgálatok során az életkor mellett a hypertonia jelenléte bizonyult a CV másik jelentős prediktorának. Több munkacsoport kimutatta a HT és a CV csökkenésének összefüggését, melynek hátterében a chorioideában létrejövő arteriosclerosis és a magas intravascularis nyomás következtében kialakuló vascularis kontrakció jelenlétét feltételezik [25]. Jelen vizsgálatunkban - a teljes beteganyagot vizsgálva - szignifikáns összefüggést mutattunk ki a chorioidea elvékonyodása és az életkor $(30 \mu \mathrm{m} / 10$ év a teljes macularis régióban), valamint a hypertonia jelenléte között. Cukorbetegekben a diabetes fennállási ideje és a chorioidea elvékonyodása között mutattunk ki szignifikáns össze-

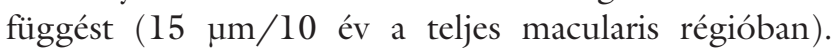
A szisztémás rizikófaktorokat többváltozós modellben vizsgálva a betegség fennállási ideje maradt a CV-csökkenés szignifikáns prediktora (az egyéb szisztémás rizikófaktorok - életkor, hypertonia, a diabetes típusa, $\mathrm{HbA}_{\mathrm{lc}^{-}}$ szint - hatását figyelembe véve).

Tanulmányunk egyik gyengesége a viszonylag alacsony betegszám. Továbbá, miután vizsgálatunk nem prospektív követéses vizsgálat volt, eredményeink alapján nem lehet egyértelmúen meghatározni az ok-okozati összefüggéseket a vizsgált rizikófaktorok és a chorioideavastagság között.

\section{Következtetés}

A chorioideavastagságot ismerten befolyásolják szisztémás rizikófaktorok. Vizsgálatunk azt igazolta, hogy e tényezők (életkor, hypertonia, a DM fennállási ideje) mellett a DM jelenléte és a DR progressziója is hatással van a chorioidea elvékonyodására. A továbbiakban kimutattuk, hogy a betegség kezelésére szolgáló panretinalis lézerkezelés hatására a chorioideavastagság szignifikáns csökkenése figyelhető meg.
A tanulmányunkban alkalmazott legújabb generációs swept source OCT hasznos noninvazív eszköznek bizonyult a chorioideavastagság pontos detektálására. A korai diabeteses chorioidopathia azonban olyan choriocapillaris változásokhoz társulhat, amelyek túl kis mértékúek ahhoz, hogy keresztmetszeti OCT-vel kimutathatók legyenek. A cukorbetegség hatására a chorioideában bekövetkező változások és a chorioidea diabeteses retinopathia patogenezisében játszott szerepének jobb megértéséhez a továbbiakban vizsgálataink folytatását tervezzük angio-OCT-vel.

Anyagi támogatás: A közlemény megírása, illetve a kapcsolódó kutatómunka anyagi támogatásban nem részesült.

Szerzői munkamegosztás: A vizsgálat tervezése: H. H., E. M., K. I., S. G. L., M. K., C. C., N. Z. Zs., S. A. A vizsgálatok elvégzése: H. H., E. M., M. K., C. C. Statisztikai elemzés: K. I., S. G. L., H. H. A közlemény megírása: H. H., E. M. Szakmai véleményezés: S. A., N. Z. Zs. A cikk végleges változatát valamennyi szerző elolvasta és jóváhagyta.

Érdekeltségek: A szerzőknek nincsenek érdekeltségeik.

\section{Irodalom}

[1] Tóth G, Szabó D, Sándor GL, et al. Diabetes and diabetic retinopathy in people aged 50 years and older in Hungary. $\mathrm{Br} \mathrm{J}$ Ophthalmol. 2017; 101: 965-969.

[2] Williams R, Airey M, Baxter H, et al. Epidemiology of diabetic retinopathy and macular oedema: a systematic review. Eye (Lond). 2004; 18: 963-983.

[3] Lee R, Wong TY, Sabanayagam C. Epidemiology of diabetic retinopathy, diabetic macular edema and related vision loss. Eye Vis (Lond). 2015; 2: 17.

[4] Czakó C, Sándor GL, Ecsedy M, et al. Evaluation of diabetic microangiopathy using optical coherence tomography angiography. [Diabeteses kisér-károsodás vizsgálata optikai koherencia tomográfián alapuló angiográfiával.] Orv Hetil. 2018; 159: 320326. [Hungarian]

[5] Wong TY, Klein R. The epidemiology of eye diseases in diabetes. In: Ekoé JM, Rewers M, Williams R, et al. (eds.). The epidemiology of diabetes mellitus (2nd edn). John Wiley and Sons, Oxford, 2008; pp. 475-497.

[6] Melancia D, Vicente A, Cunha JP, et al. Diabetic choroidopathy: a review of the current literature. Graefes Arch Clin Exp Ophthalmol. 2016; 254: 1453-1461.

[7] Campos A, Campos EJ, Martins J, et al. Viewing the choroid: where we stand, challenges and contradictions in diabetic retinopathy and diabetic macular oedema. Acta Ophthalmol. 2017; 95: 446-459.

[8] Ünsal E, Eltutar K, Zirtiloğlu S, at al. Choroidal thickness in patients with diabetic retinopathy. Clin Ophthalmol. 2014; 8: 637-642.

[9] Nickla DL, Wallman J. The multifunctional choroid. Prog Retin Eye Res. 2010; 29: 144-168.

[10] Cao J, McLeod S, Merges CA, et al. Choriocapillaris degeneration and related pathologic changes in human diabetic eyes. Arch Ophthalmol. 1998; 116: 589-597. 
[11] Lutty GA. Diabetic choroidopathy. Vision Res. 2017; 139: 161167.

[12] Shiragami C, Shiraga F, Matsuo T, at al. Risk factors for diabetic choroidopathy in patients with diabetic retinopathy. Graefes Arch Clin Exp Ophthalmol. 2002; 240: 436-442.

[13] Freeman WR, Bartsch DU, Mueller AJ, et al. Simultaneous indocyanine green and fluorescein angiography using a confocal scanning laser ophthalmoscope. Arch Ophthalmol. 1998; 116: 455463.

[14] Laviers H, Zambarakji H. Enhanced depth imaging-OCT of the choroid: a review of the current literature. Graefes Arch Clin Exp Ophthalmol. 2014; 252: 1871-1883.

[15] Ruiz-Medrano J, Flores-Moreno I, Peña-García P, et al. Macular choroidal thickness profile in a healthy population measured by swept-source optical coherence tomography. Invest Ophthalmol Vis Sci. 2014; 55: 3532-3542.

[16] Copete S, Flores-Moreno I, Montero JA, at al. Direct comparison of spectral-domain and swept-source OCT in the measurement of choroidal thickness in normal eyes. Br J Ophthalmol. 2014; 98: 334-338.

[17] Zafar S, Siddiqui MA, Shahzad R. Comparison of choroidal thickness measurements between spectral-domain OCT and swept-source OCT in normal and diseased eyes. Clin Ophthalmol. 2016; 10: 2271-2276.

[18] Giuffrè G, Lodato G, Dardanoni G. Prevalence and risk factors of diabetic retinopathy in adult and elderly subjects: The Casteldaccia Eye Study. Graefe's Arch Clin Exp Ophthalmol. 2004; 242: 535-540.

[19] Early Treatment Diabetic Retinopathy Study Research Group. Grading diabetic retinopathy from stereoscopic color fundus photographs - an extension of the modified Airlie House classification: ETDRS report number 10. Ophthalmology 1991; 98(5 Suppl): 786-806

[20] Otani T, Kishi S, Maruyama Y. Patterns of diabetic macular edema with optical coherence tomography. Am J Ophthalmol. 1999; 127: 688-693.

[21] Zhang Z, Meng X, Wu Z, et al. Changes in choroidal thickness after panretinal photocoagulation for diabetic retinopathy: a 12 week longitudinal study. Invest Ophthalmol Vis Sci. 2015; 56: $2631-2638$

[22] Wang J, Gao X, Huang W, et al. Swept-source optical coherence tomography imaging of macular retinal and choroidal structures in healthy eyes. BMC Ophthalmol. 2015; 15: 122.

[23] Han YS, Lim HB, Lee SH, et al. Diurnal variation in choroidal and retinal thickness of the early treatment of diabetic retinopathy study macular subfields determined using swept-source optical coherence tomography. Ophthalmologica 2015; 233: 192197.

[24] Bafiq R, Mathew R, Pearce E, et al. Age, sex, and ethnic variations in inner and outer retinal and choroidal thickness on spectral-domain optical coherence tomography. Am J Ophthalmol. 2015; 160: 1034-1043.el.
[25] Akay F, Gundogan FC, Yolcu U, et al. Choroidal thickness in systemic arterial hypertension. Eur J Ophthalmol. 2016; 26: 152-157.

[26] Regatieri CV, Branchini L, Carmody J, et al. Choroidal thickness in patients with diabetic retinopathy analyzed by spectral-domain optical coherence tomography. Retina 2012; 32: 563-568.

[27] Horváth H, Kovács I, Sándor GL, et al. Choroidal thickness changes in non-treated eyes of patients with diabetes: sweptsource optical coherence tomography study. Acta Diabetol. 2018; 55: 927-934.

[28] Querques G, Lattanzio R, Querques L, et al. Enhanced depth imaging optical coherence tomography in type 2 diabetes. Invest Ophthalmol Vis Sci. 2012; 53: 6017-6024.

[29] Laíns I, Talcott KE, Santos AR, et al. Choroidal thickness in diabetic retinopathy assessed with swept-source optical coherence tomography. Retina 2018; 38: 173-182.

[30] Kim JT, Lee DH, Joe SG, et al. Changes in choroidal thickness in relation to the severity of retinopathy and macular edema in type 2 diabetic patients. Invest Ophthalmol Vis Sci. 2013; 54: 3378-3384.

[31] de Freytas A, Gallego Pinazo R, Cisneros Lanuza Á. Subfoveal choroidal thickness in eyes with diabetic macular oedema using swept source optical coherence tomography. [Grosor coroideo subfoveal medido con tomografía de coherencia óptica swept source en ojos con edema macular diabético.] Arch Soc Esp Oftalmol. 2016; 91: 228-231. [Spanish]

[32] Vujosevic S, Martini F, Cavarzeran F, et al. Macular and peripapillary choroidal thickness in diabetic patients. Retina 2012; 32: $1781-1790$.

[33] Huang D, Swanson EA, Lin CP, et al. Optical coherence tomography. Science 1991; 254: 1178-1181.

[34] Evans JR, Michelessi M, Virgili G. Laser photocoagulation for proliferative diabetic retinopathy. Cochrane Database Syst Rev. 2014; 2014: CD011234.

[35] Takahashi A, Nagaoka T, Sato E, et al. Effect of panretinal photocoagulation on choroidal circulation in the foveal region in patients with severe diabetic retinopathy. $\mathrm{Br} \mathrm{J}$ Ophthalmol. 2008; 92: 1369-1373.

[36] Roohipoor R, Sharifian E, Ghassemi F, et al. Choroidal thickness changes in proliferative diabetic retinopathy treated with panretinal photocoagulation versus panretinal photocoagulation with intravitreal bevacizumab. Retina 2016; 36: 1997-2005.

[37] Ohara Z, Tabuchi H, Nakakura S, et al. Changes in choroidal thickness in patients with diabetic retinopathy. Int Ophthalmol. 2018; 38: 279-286.

[38] Récsán Zs. Importance of choroidal thickness in eye diseases. [A chorioidea-vastagság jelentősége szemfenéki kórképekben.] Szemészet 2019; 156: 48-60. [Hungarian]

(Horváth Hajnalka dr., Budapest, Ipar u. 23. VI/2., 1095 e-mail: hajnalkahorvath88@gmail.com)

A cikk a Creative Commons Attribution 4.0 International License (https://creativecommons.org/licenses/by/4.0/) feltételei szerint publikált Open Access közlemény, melynek szellemében a cikk bármilyen médiumban szabadon felhasználható, megosztható és újraközölhető, feltéve, hogy az eredeti szerző és a közlés helye, illetve a CC License linkje és az esetlegesen végrehajtott módositások feltüntetésre kerülnek. (SID_1) 